\title{
Effect of mulching with maize straw on water infiltration and soil loss at different initial soil moistures in a rainfall simulation
}

\author{
Yifu ZHANG ${ }^{1}$, Hongwen LI $(\bowtie)^{1}$, Jin HE$^{1}$, Qingjie WANG ${ }^{1}$, Ying $\mathrm{CHEN}^{2}$, Wanzhi $\mathrm{CHEN}^{1}$, Shaochun MA $^{1}$ \\ 1 College of Engineering, China Agricultural University, Beijing 100083, China \\ 2 Department of Biosystems Engineering, University of Manitoba, Winnipeg R3T 5V6, Canada
}

\begin{abstract}
Mulching and soil water content (SWC) have a significant impact on soil erosion, and this study investigated the effect of straw mulching on water infiltration and soil loss under different initial SWC treatments in a rainfall simulation experiment conducted in northern China. Increasing initial SWC can decrease soil infiltration and increase soil loss. During an $80 \mathrm{~mm}$ rainfall event $\left(80 \mathrm{~mm} \cdot \mathrm{h}^{-1}\right.$ for $\left.60 \mathrm{~min}\right), 8 \%, 12 \%$ and $16 \%$ initial SWC treatments decreased cumulative infiltration by $8.7 \%, 42.5 \%$ and $58.1 \%$, and increased total sediment yield by 44,146 and $315 \mathrm{~g}$, respectively, compared to $4 \%$ initial SWC. However, in all the straw mulching treatments, there was no significant difference in stable infiltration rate between the different initial SWC treatments. For all initial SWC treatments, straw mulching of $30 \%$ or more significantly enhanced water infiltration by over $31 \%$ and reduced soil loss by over $49 \%$, compared to the unmulched treatment. Taking into consideration the performance of no-till planters, a maize straw mulching rate of $30 \%$ to $60 \%\left(1400-3100 \mathrm{~kg} \cdot \mathrm{hm}^{-2}\right)$ is recommended for the conservation of water and soil in northern China.
\end{abstract}

Keywords infiltration, initial soil water content, rainfall simulation, soil loss, straw mulching

\section{Introduction}

Long-term application of traditional management practices in agricultural production have resulted in aggravated

Received May 4, 2016; accepted June 7, 2016

Correspondence: 1hwen@cau.edu.cn drought, resource shortage and environmental deterioration $^{[1]}$, which has affected grain production and the sustainability of agricultural development in China. This situation is particularly serious in northern China, which has about $3300 \times 10^{4} \mathrm{hm}^{2}$ of farmland affected by soil erosion $^{[2]}$. Soil surface mulching with a layer of crop straw is an effective method for conserving water and soil because it can reduce surface runoff, increase soil infiltration and prevent soil erosion ${ }^{[3,4]}$.

Studies around the world have highlighted the importance of crop straw mulching, because it increases soil porosity $^{[5]}$, enhances water infiltration ${ }^{[6,7]}$, and reduces runoff and soil erosion ${ }^{[8]}$. Also, straw mulching has been reported to decrease soil crusting after heavy rainfall events by absorbing kinetic energy of the raindrops ${ }^{[9]}$. In dry climates, Cameron et al. indicated that residue retention can significantly increase rainfed crop productivity $^{[10]}$. On the arid North China Plain, straw mulching has been shown to increase water use efficiency in its double cropping system ${ }^{[11]}$. In subtropical regions, mulching has been effective, especially on sloping land ${ }^{[12-14]}$. Furthermore, straw mulching has been shown to protect farmlands ${ }^{[15]}$, by improving soil physical properties ${ }^{[16]}$, increasing soil fertility ${ }^{[17]}$ and controlling evaporation ${ }^{[18]}$.

Initial soil water content (SWC), which influences runoff and water infiltration, has been well documented ${ }^{[19,20]}$. An increase in SWC decreases the hydraulic gradient ${ }^{[21]}$, and thus reduces the driving force responsible for water infiltration into the soil. The effect of initial SWC on the stability of microrelief has been investigated using laboratory rainfall simulation ${ }^{[22]}$. The role of initial SWC in determining the local water pathways has also been recognized at a field scale ${ }^{[23,24]}$. Focusing on soil crusting phenomena, Casenave and Valentin ${ }^{[25]}$ studied another role of initial SWC in hydrological response compared to soil surface characteristics. 
In China, the effects of initial SWC on soil moisture distribution have been reported, and the results showed that as initial SWC increased the time needed to wet soil surface was reduced and the expansion of the wetting front was more rapid both horizontally and vertically in bubble irrigation ${ }^{[26]}$. Earlier runoff, lower average infiltration rate and shorter time to reach stable infiltration rate occurred when initial SWC increased during rainfall simulation ${ }^{[27]}$. Triaxial shearing test data indicated that soil cohesive force first increased then decreased with increasing SWC, and the maximum of soil cohesive force was found at the water content of about $10 \%\left[{ }^{[28]}\right.$. Fan et al. ${ }^{[29]}$ simulated the infiltration characteristics of a range of typical soils under different initial SWC, and the results indicated that the variation of cumulative infiltration was consistent with the Philip model. In addition, soil infiltrability and initial SWC have been researched by different methods, such as the double-ring method and the run-off-on-out method ${ }^{[30]}$.

In northern China, summer maize (Zea mays), one of the most commonly grown crops ${ }^{[31]}$, is essential for maintaining food security. In this region, the influence of maize straw mulching on improving agricultural ecological environment $^{[32]}$, promoting crop growth ${ }^{[33]}$ and increasing grain yield ${ }^{[34]}$ has been reported. Due to the application of irrigation during crop growth, the initial SWC can vary, sometimes substantially, within the maize planting region of northern China, which can affect water infiltration and soil erosion during the rainy season. Based on the literature cited above, research in China, using different methods, has mostly focused on the influence of initial SWC on the infiltration characteristics. However, there has been limited research on the effect of initial SWC on runoff and soil loss under straw mulching management. Therefore in this study, the effect of maize straw as a mulching material on soil infiltration and soil loss under different initial SWC was investigated using laboratory rainfall simulation. The objective was to determine straw mulching rates that can limit soil loss under different initial SWC, and to provide a theoretical base for straw management in summer maize in northern China grown in conservation tillage systems.

\section{Materials and methods}

\subsection{Site and climatic conditions}

A rainfall simulation experiment was conducted at the Zhuozhou Experimental Station, China Agricultural University ( $39^{\circ} 28^{\prime} \mathrm{N}, 115^{\circ} 56^{\prime}$ E), Hebei Province, China, from October 2013 to May 2014. The microclimate of the area is semi-arid, with an average annual rainfall of $536 \mathrm{~mm}$, which mostly falls between June and September (Fig. 1). Average annual temperature is $11.9^{\circ} \mathrm{C}$ with 186 frost-free days. The field capacity at the experimental site is $20.3 \%$, and the soil type is defined as sandy loam according to the USDA texture classification system. The bulk density was $1.34 \mathrm{~g} \cdot \mathrm{cm}^{-3}$, the organic matter content was $19.0 \mathrm{~g} \cdot \mathrm{kg}^{-1}$ and the $\mathrm{pH}$ was 7.8 in the top $300 \mathrm{~mm}$ soil layer.

\subsection{Experimental design}

The objective was to determine straw mulching management solutions under different initial soil water content conditions. In order to get a natural soil condition for rainfall simulation, the undisturbed soil was removed from farmland and placed in a soilbin. The soil type was sandy loam, which is one of the most common soils in northern China. The position of the soilbin could be adjusted to give different soil surface gradients. In this experiment, the soil surface gradient was set to $9 \%$. So the influence of soil type and surface gradient on water infiltration and soil loss could be avoided.

Four different percentages of initial SWC (4\%, 8\%, $12 \%$ and $16 \%$ ) were used in this experiment. The $4 \%$ water content (equivalent to $20 \%$ of the field capacity), which simulated a dry soil condition, was adopted as the base value. The other three, which were equivalent to $40 \%, 60 \%$ and $80 \%$ of the field capacity, were applied to simulate normal to wet soil conditions. In each initial SWC condition, four different straw mulching rates (SMR), giving coverage of $0 \%, 15 \%, 30 \%$ and $60 \%$, were used to investigate the effect of mulching on soil loss.

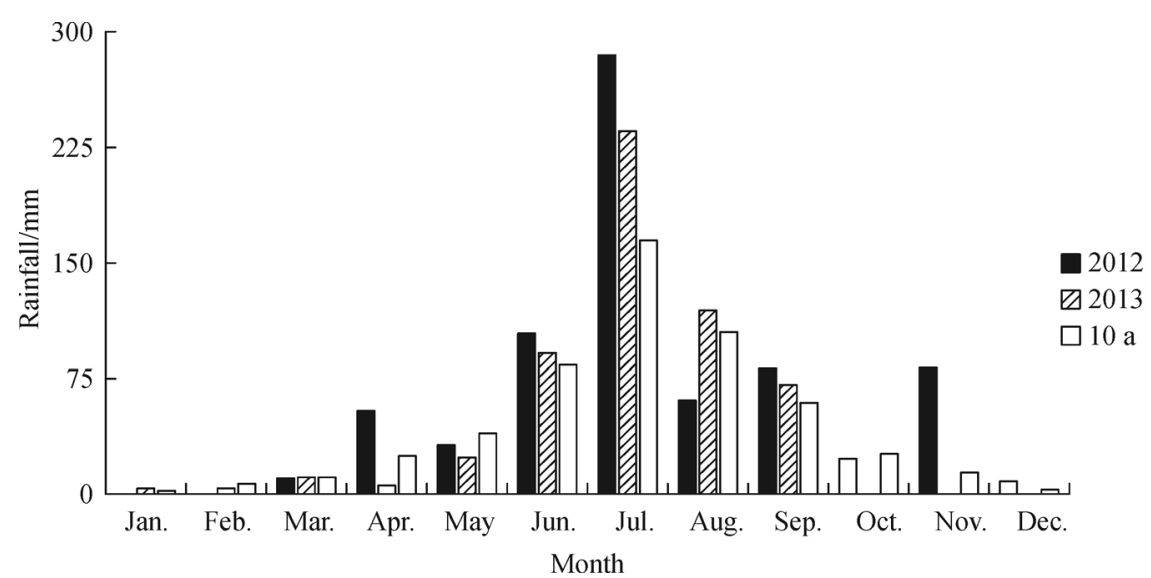

Fig. 1 Monthly rainfall distribution in 2012 and 2013 (January to September only), and the average for the past 10 years 
The meteorological data from an outdoor meteorological station at the experimental site showed that the rainfall intensity reached as high as $82 \mathrm{~mm} \cdot \mathrm{h}^{-1}$ during rainfall events in 2012 and 2013. Thus, in this study a rainfall intensity of $80 \mathrm{~mm} \cdot \mathrm{h}^{-1}$ was simulated, given that runoff occurs mainly in heavy rainfall events ${ }^{[35]}$.

The design was a full factorial combination of the four SWC and four SMR treatments. Each treatment combination was replicated three times to give a total of 48 tests. The duration of each rainfall simulation test was $60 \mathrm{~min}$.

\subsection{Soil water preparation}

For the rainfall simulation, soil from the top $300 \mathrm{~mm}$ layer was collected from the experimental site. The soil was airdried (4\% $\mathrm{g} \cdot \mathrm{g}^{-1}$ soil mass moisture) and visible organic material was removed. The soil was gently crushed by hand to pass through a $5 \mathrm{~mm}$ sieve. Soil materials with different initial SWC treatments were prepared using the following steps ${ }^{[35]}$ :

(1) Determining the air-dried soil water content by an oven drying method;

(2) Calculating the required water addition as the treatment water content minus the measured water content;

(3) Adding water and mixing uniformly to obtain the predefined water content; and

(4) Storing the moistened soil in a sealed plastic drum until used in the rainfall experiment.

\subsection{Testing equipment}

A soilbin (length, $1 \mathrm{~m}$; width, $1 \mathrm{~m}$; depth, $350 \mathrm{~mm}$; slope, $9 \%$ ) was filled with undisturbed soil (height, $300 \mathrm{~mm}$; bulk density, $1.34 \mathrm{~g} \cdot \mathrm{cm}^{-3}$ ). The bottom of the soilbin had evenly distributed $4 \mathrm{~mm}$ holes (100 $\mathrm{mm}$ apart) to remove the influence of the closed soilbin on soil water infiltration. A channel (diameter, $50 \mathrm{~mm}$; length, $100 \mathrm{~mm}$ ) was mounted on the front of the soilbin, $100 \mathrm{~mm}$ high from the bin bottom, to collect runoff water.

Air-dry maize straw was collected from fields after harvesting in early October and manually cut in pieces of $50-100 \mathrm{~mm}$ long, and the predefined amount of straw was spread uniformly on the soil surface.

A rainfall simulator (model, DIK-6000, Daiki Rika Kogyo Co. Ltd., Tokyo, Japan) with rainfall intensities of 10 to $120 \mathrm{~mm} \cdot \mathrm{h}^{-1}$ was used to simulate rainfall. The available rainfall area (length, $1.1 \mathrm{~m}$; width, $1.1 \mathrm{~m}$ ) was $1.21 \mathrm{~m}^{2}$, the rainfall height was $2 \mathrm{~m}$, and the raindrop diameter range was between 1.7 and $3.0 \mathrm{~mm}$.

\subsection{Measurements}

\subsubsection{Runoff and sediment loss}

Rainfall calibration tests were conducted to ensure that the rainfall intensity was accurate. The time when runoff occurred was recorded, and runoff samples collected for each simulation. The runoff sample was collected once per minute for the first $10 \mathrm{~min}$, and then once per $5 \mathrm{~min}$ for the remaining time.

After the sediment was filtered from the runoff samples, the volume of the runoff water was measured with a graduated cylinder, and the collected sediment was ovendried at $105^{\circ} \mathrm{C}$ for $24 \mathrm{~h}$. The volume of the runoff water was divided by interval time to determine the runoff flow rate. The amount of dry sediment was weighed to determine the sediment loss in the runoff.

\subsubsection{Maize straw mulching rate}

The maize SMR was determined by weight using the procedure of Liu et al., combining image processing and regression analysis ${ }^{[36]}$. The quantitative relationship between maize SMR and the straw weight was calculated by the following equation:

$$
\mathrm{SMR}=-1.89 \times 10^{-8} x^{2}+2.7 \times 10^{-4} x-4.92 \times 10^{-2}
$$

where $x$ is the weight of maize straw, $\mathrm{kg} \cdot \mathrm{hm}^{-2}$.

The corresponding straw rate was $800 \mathrm{~kg} \cdot \mathrm{hm}^{-2}$ for the $15 \%$ SMR treatment, $1400 \mathrm{~kg} \cdot \mathrm{hm}^{-2}$ for the $30 \%$ SMR treatment, and $3100 \mathrm{~kg} \cdot \mathrm{hm}^{-2}$ for the $60 \%$ SMR treatment.

During the preparation of each SMR condition, the calculated and weighed maize straws were spread uniformly on the soil surface of soilbin to simulate straw mulching condition of farmland. By uniformly spreading, the difference in mulching thickness under each SMR condition was not significant, so any influence of mulching thickness on the experimental result could be ignored.

\subsubsection{Infiltration rate and cumulative infiltration}

Infiltration rate in the absence of rainfall is commonly measured with a cylinder infiltrometer ${ }^{[37]}$. The double-ring infiltrometer is a standard technique for direct measurement of soil infiltration rate ${ }^{[38]}$, but it cannot be applied to a naturally sloped surface. Ignoring the rain period evaporation and vegetation intercept, soil infiltration rate during the different sampling periods was calculated by the following formula ${ }^{[30]}$ :

$$
i=P \cos \alpha-\frac{q}{S}
$$

where $i$ is the soil infiltration rate, $\mathrm{mm} \cdot \mathrm{min}^{-1} ; P$ is the rainfall intensity, $\mathrm{mm} \cdot \mathrm{min}^{-1} ; \alpha$ is the gradient of land surface, ${ }^{\circ} ; q$ is the runoff flow rate at the outlet of the experimental slope, $\mathrm{L} \cdot \mathrm{min}^{-1}$; and $s$ is the slope surface area, $\mathrm{m}^{2}$.

$\mathrm{Li}$ and Shao expressed cumulative infiltration as a function of integral equation, which was the integral of 
infiltration rate with respect to time ${ }^{[39]}$ :

$$
I=\int_{0}^{t} i \mathrm{~d} t
$$

where $I$ is the cumulative infiltration, $\mathrm{mm} ; i$ is the soil infiltration rate, $\mathrm{mm} \cdot \mathrm{min}^{-1}$; and $t$ is the runoff-yield time, $\min$.

\subsection{Statistical analysis}

The SPSS analytical software (22.0, IBM SPSS Inc.; Chicago, IL, USA.) was used for all of the statistical analyses. Mean values were calculated for each of the measurements, and ANOVA was used to assess the treatment effects on the measured variables. When ANOVA indicated a significant $F$-value, multiple comparisons of annual mean values were made on the basis of the least significant difference (LSD).

\section{Results}

\subsection{Infiltration rate}

Figure 2 shows the soil infiltration rate measured during the rainfall simulation under four different SMR treatments for each initial SWC. Overall, the infiltration rate decreased rapidly in the early stage of runoff, and then tended to stabilize.

With $4 \%$ initial SWC, the infiltration curves showed that $15 \%, 30 \%$ and $60 \%$ SMR moderated the decrease in infiltration rate, and delayed the times to stable infiltration by 5,10 and $15 \mathrm{~min}$, respectively, when compared to $0 \%$ SMR. However, with $16 \%$ initial SWC, the infiltration rate decreased rapidly at the beginning of runoff. Meanwhile, under different SMR, the difference in time to steady infiltration was not significant. With $8 \%$ and $12 \%$ initial SWC treatments, the influence of SMR on infiltration was similar to that obtained with the $4 \%$ initial SWC.

For all initial SWC treatments, increased SMR resulted in an increased stable infiltration rate. With the $4 \%$ initial SWC, the stable infiltration rate ranged from 0.19 to $0.45 \mathrm{~mm} \cdot \mathrm{min}^{-1}$, and compared to $0 \% \mathrm{SMR}$ treatment, the stable infiltration rates with $30 \%$ and $60 \%$ SMR were 0.12 and $0.26 \mathrm{~mm} \cdot \mathrm{min}^{-1}$ higher $(P<0.05)$, respectively. With $8 \%$ initial SWC, the stable infiltration rate ranged from 0.18 to $0.45 \mathrm{~mm} \cdot \mathrm{min}^{-1}$, and with $30 \%$ and $60 \% \mathrm{SMR}$, the stable infiltration rates were 0.12 and $0.27 \mathrm{~mm} \cdot \mathrm{min}^{-1}$, which were greater $(P<0.05)$ than with the $0 \%$ SMR. Similar results were found with $12 \%$ and $16 \%$ initial SWC

Straw mulching rate $/ \%$

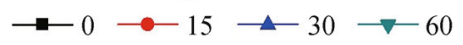

(a)

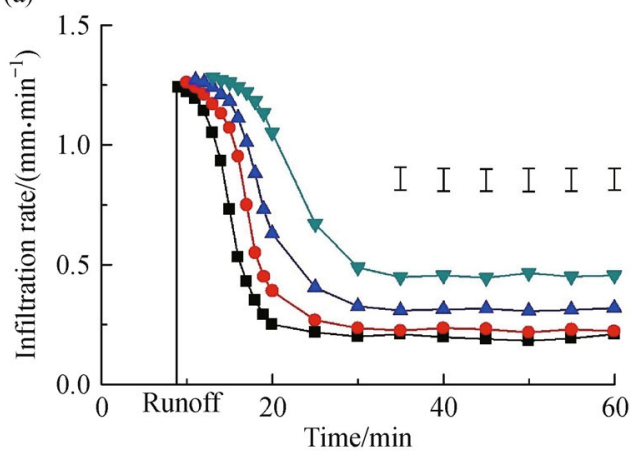

(c)

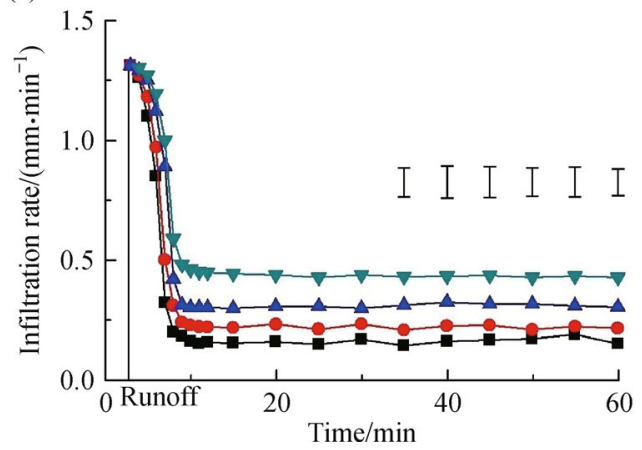

(b)

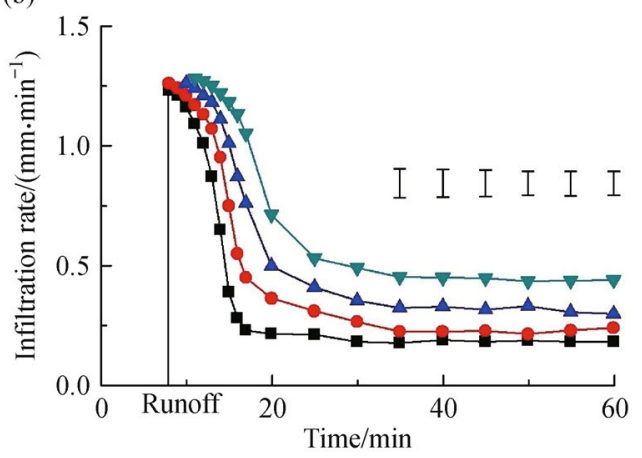

(d)

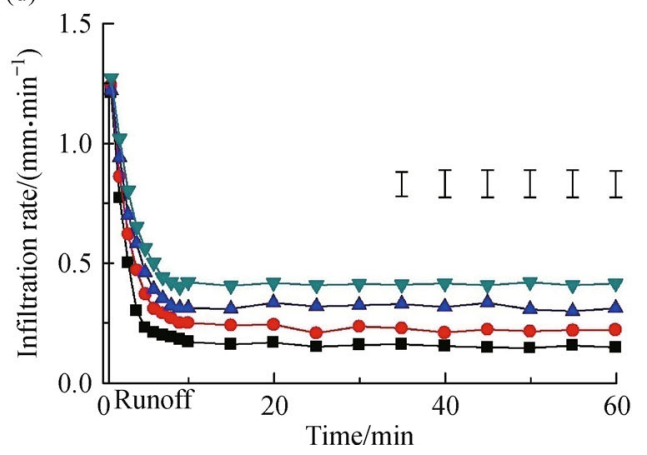

Fig. 2 Infiltration rate as a function of time determined by the simulated rainfall $\left(80 \mathrm{~mm} \cdot \mathrm{h}^{-1}\right.$ for $\left.1 \mathrm{~h}\right)$ for an initial soil water content of $4 \%$ (a), $8 \%$ (b), $12 \%$ (c) and 16\% (d), under four different straw mulching rates. On the $x$-axis, 0 is the beginning of simulated rainfall and the beginning of runoff is shown by the vertical line. Bars show LSD values $(P<0.05)$ in the stable infiltration stage. 
treatments, and the stable infiltration rates under the $30 \%$ and $60 \%$ SMR were $>0.15$ and $>0.28 \mathrm{~mm} \cdot \mathrm{min}^{-1}$ $(P<0.05)$, respectively, which were higher than that with the $0 \%$ SMR. The straw mulching treatments all improved infiltration, compared to the unmulched treatment. However, for all the straw mulching treatments, there was no statistically significant difference in the stable infiltration rate between the different initial SWC treatments.

\subsection{Cumulative infiltration}

With different initial SWC treatments, the influence of SMR on cumulative infiltration showed a similar response to infiltration rate (Fig. 3), i.e., 60\% SMR $>30 \%$ $\mathrm{SMR}>15 \% \mathrm{SMR}>0 \% \mathrm{SMR}$. In an $80 \mathrm{~mm}$ rainfall event $\left(80 \mathrm{~mm} \cdot \mathrm{h}^{-1}\right.$ for $\left.1 \mathrm{~h}\right)$ with $4 \%$ initial SWC, $30 \%$ and $60 \%$ SMR enhanced the cumulative infiltration significantly $(P<0.05)$ by $31.8 \%$ and $60.9 \%$ relative to the $0 \%$ SMR $(27.9 \mathrm{~mm})$. With $8 \%$ initial SWC, the cumulative infiltrations with $30 \%$ and $60 \%$ SMR were $38.9 \%$ and $65.6 \%$, respectively, which were significantly $(P<0.05)$ higher than with the $0 \%$ SMR. With $12 \%$ and $16 \%$ initial SWC treatments, the cumulative infiltrations showed the same trend and the values with $30 \%$ and $60 \%$ SMR were over 55\%, which was significantly $(P<0.05)$ higher than with the 0\% SMR. However, with all the initial SWC, the differences in cumulative infiltrations between the unmulched treatment and 15\% SMR was not significant. The results indicated that $>30 \%$ SMR significantly $(P<0.05)$ increased the cumulative infiltration, and under the same straw mulching treatment, the cumulative infiltration decreased with the increasing in initial SWC.

\subsection{Runoff time}

Generally, straw mulching delayed runoff time (i.e., the time until runoff occurred) (Table 1) for all initial SWC treatments. With $4 \%$ initial SWC, the runoff time was delayed by increasing SMR, and the values with $30 \%$ and $60 \%$ SMR were 2.4 and 3.5 min later $(P<0.05)$ than that of the unmulched treatment, respectively. However, there was no significant difference in runoff time for $10 \%$ and $15 \%$ SMR. With $8 \%$ initial SWC, when compared to the unmulched treatment, the corresponding runoff times for $30 \%$ and $60 \%$ SMR treatments were 2.1 and 3.2 min later $(P<0.05)$, but $15 \%$ SMR gave no significant difference in runoff time. For $12 \%$ and $16 \% \mathrm{SWC}$ treatments, there was no significant effect of SWR on runoff time.

For the unmulched treatment, the runoff times for the $12 \%$ and $16 \%$ initial SWC treatments were 6.5 and
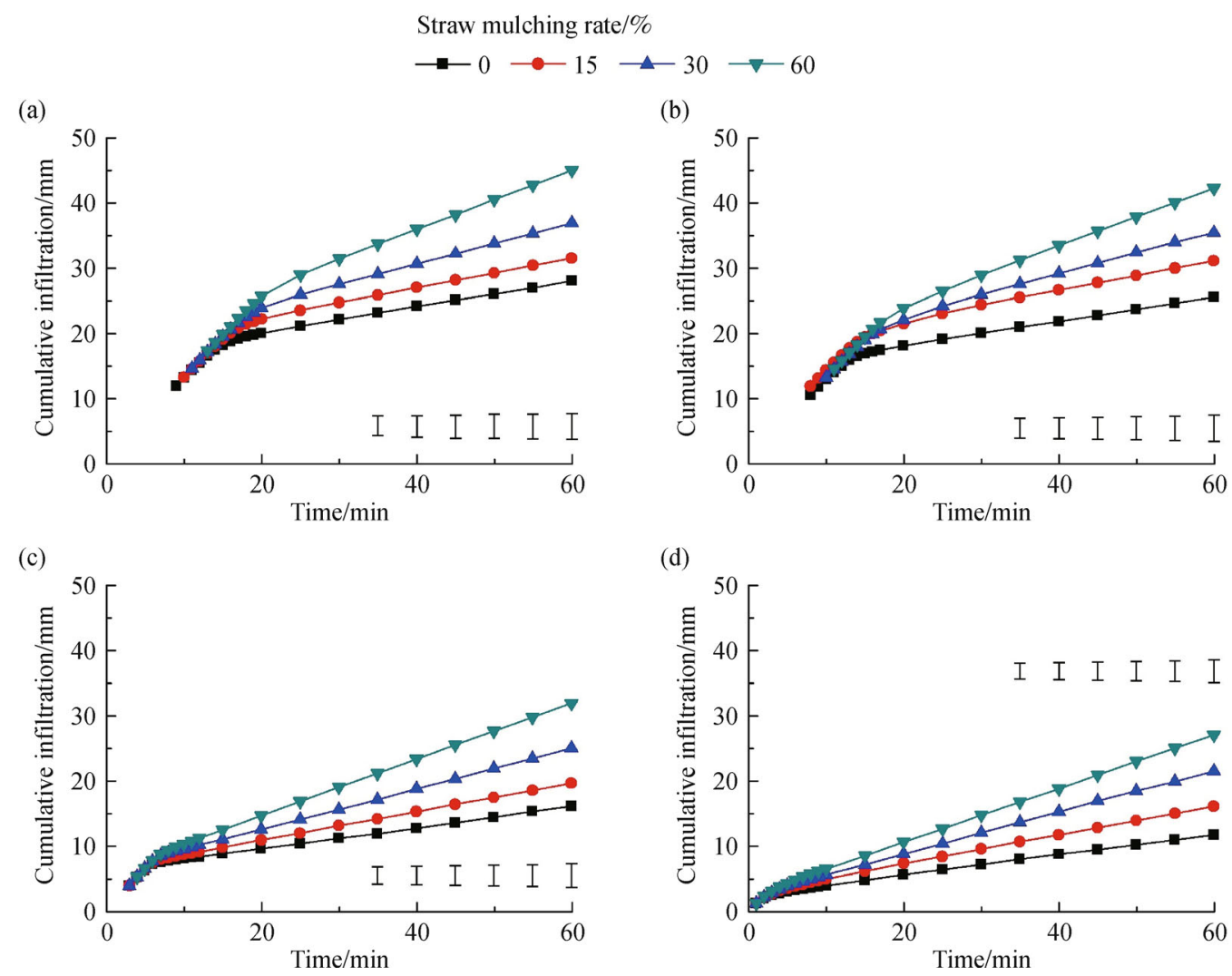

Fig. 3 Cumulative infiltration as a function of time determined by the simulated rainfall $\left(80 \mathrm{~mm} \cdot \mathrm{h}^{-1}\right.$ for $\left.1 \mathrm{~h}\right)$ for an initial soil water content of $4 \%$ (a), $8 \%$ (b), $12 \%$ (c) and $16 \%$ (d), under four different straw mulching rates. Bars show LSD values $(P<0.05)$ in the stable infiltration stage. 
Table 1 Runoff time* (min) for four straw mulching rates with four different initial soil water contents

\begin{tabular}{|c|c|c|c|c|}
\hline \multirow{2}{*}{ Initial soil water content $/ \%$} & \multicolumn{4}{|c|}{ Straw mulching rate $/ \%$} \\
\hline & 0 & 15 & 30 & 60 \\
\hline 4 & $8.6 \pm 0.66 a$ & $9.4 \pm 0.64 a$ & $11.0 \pm 0.75 b$ & $12.1 \pm 0.71 \mathrm{~b}$ \\
\hline 8 & $7.3 \pm 0.60 \mathrm{a}$ & $7.9 \pm 0.33 \mathrm{a}$ & $9.4 \pm 0.56 b$ & $10.5 \pm 0.45 \mathrm{c}$ \\
\hline 12 & $2.1 \pm 0.46 \mathrm{a}$ & $2.6 \pm 0.62 \mathrm{a}$ & $2.7 \pm 0.70 \mathrm{a}$ & $3.2 \pm 0.65 \mathrm{a}$ \\
\hline 16 & $0.4 \pm 0.20 \mathrm{a}$ & $0.4 \pm 0.22 \mathrm{a}$ & $0.3 \pm 0.12 \mathrm{a}$ & $0.7 \pm 0.23 \mathrm{a}$ \\
\hline
\end{tabular}

Note: *, Runoff time is defined as the time between commencement of the simulated rainfall treatment and runoff commencing. Values within a row followed by different letters are significantly different $(P<0.05)$. Data are means $\pm \mathrm{SD}(n=3)$.

8.2 min later than with $4 \%$ initial SWC. For SMR treatments, the influence of initial SWC on the runoff time was similar to that of the unmulched treatment, indicating that the increase in initial SWC can result in the earlier runoff.

\subsection{Sediment yield rate and total sediment yield}

In the early stage of runoff, the initial sediment yield rate decreased with the increasing SMR for all the initial SWC treatments (Fig. 4). With 4\%, $8 \%$ and $12 \%$ initial SWC treatments, sediment yield rate increased and then tended to stabilize. However, with $16 \%$ initial SWC, the sediment yield rate decreased at the beginning of runoff and then tended to stabilize under $0 \%, 15 \%$ and $30 \%$ SMR. Under the $60 \%$ SMR, the sediment yield rate was relatively stable without a rapid decrease.

In the late stage of runoff, with all the initial SWC treatments, straw mulching treatments decreased the stable sediment yield rate. With $4 \%$ initial SWC, the stable sediment yield rates in the $15 \%, 30 \%$ and $60 \%$ SMR treatments were $36.4 \%, 49.6 \%$ and $61.4 \%$ lower $(P<0.05)$ than with the $0 \%$ SMR, respectively. With $8 \%$ initial SWC, the stable sediment yield rates with $15 \%$ and $30 \%$ SMR were $31.1 \%$ and $50.6 \%$ lower $(P<0.05)$ than with the $0 \%$ SMR. Similar results were found with $12 \%$ and $16 \%$ initial SWC treatments, and the stable sediment yield rates with $15 \%$ and $30 \%$ SMR were $>31 \%$ and $>51 \%$ lower
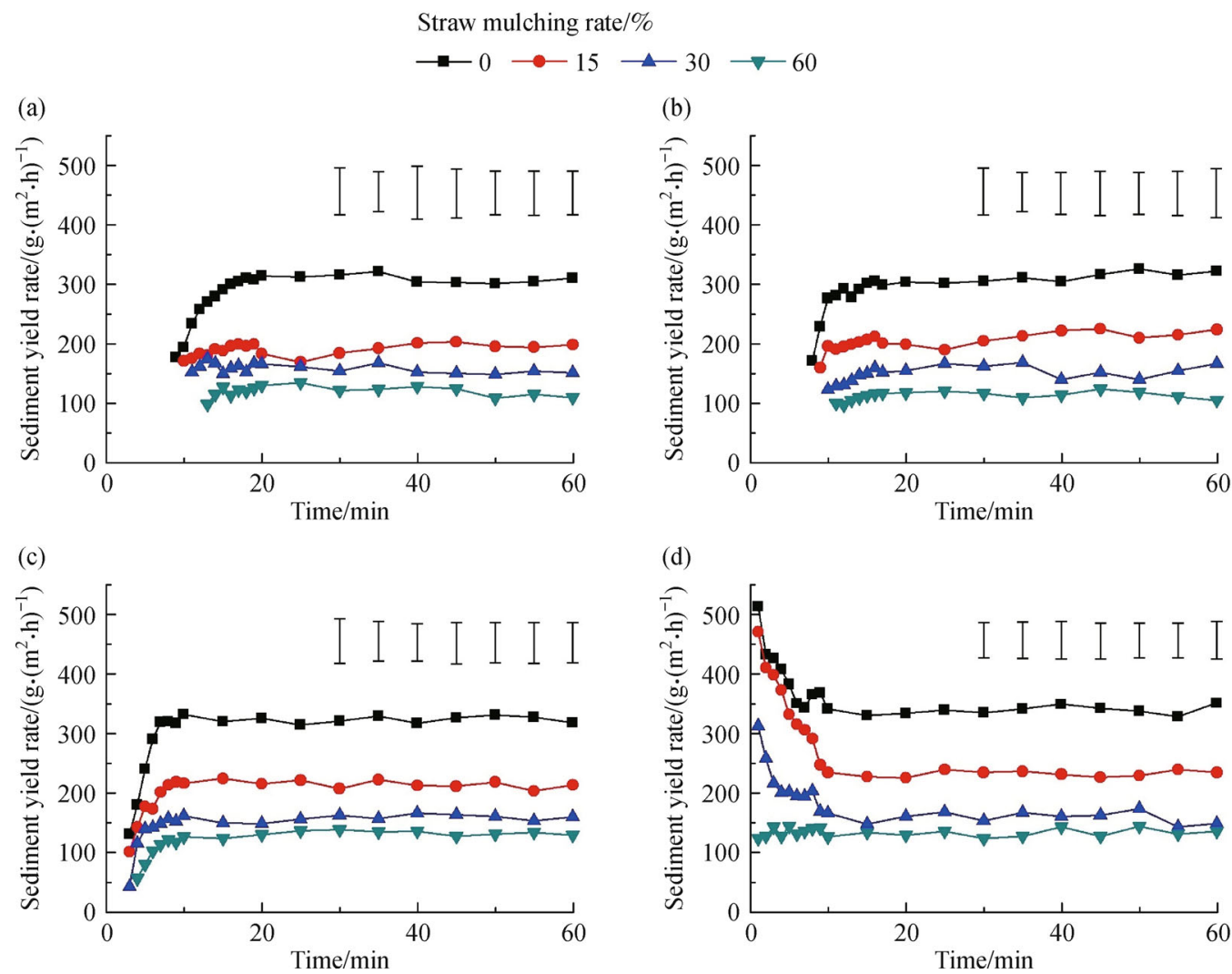

Fig. 4 Sediment yield rate as a function of time determined by the simulated rainfall $\left(80 \mathrm{~mm} \cdot \mathrm{h}^{-1}\right.$ for $\left.1 \mathrm{~h}\right)$ for initial soil water content of $4 \%$ (a), $8 \%$ (b), $12 \%$ (c) and $16 \%$ (d), under four different straw mulching rates. Bars show LSD values $(P<0.05)$ in the stable infiltration stage. 
$(P<0.05)$ than with the $0 \%$ SMR.

With different initial SWC treatments, the influence of straw mulching treatments on total sediment yield showed a similar tendency to sediment yield rate (Table 2), i.e., $60 \%$ SMR $<30 \%$ SMR $<15 \%$ SMR $<0 \%$ SMR treatment. In an $80 \mathrm{~mm}$ rainfall event, with $4 \%$ initial SWC, $15 \%$ and $30 \%$ SMR significantly $(P<0.05)$ reduced total sediment yield by $41.0 \%$ and $56.9 \%$ relative to the unmulched treatment. With $8 \%$ initial SWC, the total sediment yields with $15 \%$ and $30 \%$ SMR were $39.2 \%$ and $58.7 \%$ lower $(P<0.05)$ than with $0 \%$ SMR. With $12 \%$ and $16 \%$ initial SWC treatments, the total sediment yields showed the same trend and the value with $30 \%$ SMR was more than $49 \%$ lower $(P<0.05)$ than with $0 \%$ SMR. For all the SMR, the total sediment yields showed an increasing tendency with increasing of initial SWC. Under the unmulched treatment, the total sediment yields with $8 \%, 12 \%$ and $16 \%$ initial SWC treatments were 44 , 146 and $315 \mathrm{~g}$, respectively, and were higher than with $4 \%$ initial SWC.

Table 2 Total sediment yield determined by the simulated rainfall $\left(80 \mathrm{~mm} \cdot \mathrm{h}^{-1}\right.$ for $\left.1 \mathrm{~h}\right)$ at four different initial soil water contents and four different straw mulching rates

\begin{tabular}{lcc}
\hline $\begin{array}{l}\text { Initial soil water } \\
\text { content } / \%\end{array}$ & Straw mulching rate/\% & Total sediment yield $/ \mathrm{g}^{*}$ \\
\hline \multirow{4}{*}{4} & 0 & $295 \pm 12.7 \mathrm{a}$ \\
& 15 & $174 \pm 16.5 \mathrm{~b}$ \\
& 30 & $127 \pm 11.1 \mathrm{c}$ \\
& 60 & $100 \pm 10.4 \mathrm{~d}$ \\
& 0 & $339 \pm 15.5 \mathrm{a}$ \\
& 15 & $206 \pm 13.0 \mathrm{~b}$ \\
& 30 & $140 \pm 12.4 \mathrm{c}$ \\
& 60 & $96 \pm 11.2 \mathrm{~d}$ \\
12 & 0 & $441 \pm 19.9 \mathrm{a}$ \\
& 15 & $297 \pm 11.2 \mathrm{~b}$ \\
& 30 & $219 \pm 16.5 \mathrm{c}$ \\
& 60 & $169 \pm 14.3 \mathrm{~d}$ \\
& 0 & $610 \pm 23.8 \mathrm{a}$ \\
& 15 & $475 \pm 19.3 \mathrm{~b}$ \\
& 30 & $309 \pm 16.9 \mathrm{c}$ \\
& 60 & $223 \pm 18.6 \mathrm{~d}$ \\
\hline
\end{tabular}

Note: *, Values followed by different letters are significantly different $(P<0.05)$. Data are means $\pm \operatorname{SD}(n=3)$.

\section{Discussion}

\subsection{Initial SWC affects soil infiltration and soil loss}

In this study, the cumulative infiltrations under $8 \%, 12 \%$ and $16 \%$ initial SWC treatments were $8.7 \%, 42.5 \%$ and $58.1 \%$ lower than those under $4 \%$ initial SWC condition, and this can be explained by as follows. Firstly, the lower hydraulic gradient determines the lesser driving force of water infiltration when the initial SWC is higher, which confirmed the findings of Hillel ${ }^{[40]}$. As the initial SWC increased, the hydraulic gradient decreased and made it easy to reach a stable infiltration rate, and then a reduced cumulative infiltration. Secondly, high soil moisture conditions results in reduced soil aggregate stability and enhanced slaking forces that can cause aggregate breakdown, compared to dry soil conditions ${ }^{[41,42]}$. When initial SWC increased, the destruction of soil surface structure intensified, and consequently soil crusting developed; thus, soil infiltrability would be expected to reduce.

The stable infiltration rates under different initial SWC treatments were not significant, which is similar to the results of Bodman et al. ${ }^{[43]}$ and Liu et al. ${ }^{[4]}$. This is because of newly-formed soil crusting after rainfall events which has greater effect on soil water infiltration relative to initial SWC. However, different results were found by Liu et al. ${ }^{[45]}$ and Zhang et al. ${ }^{[46]}$ using a double-ring infiltration method and a slow release sub-surface irrigation system, which were different from the rainfall simulation used in this study. Under the above two water supply modes, the breakdown of soil aggregate and the blockage of soil pores which occurred during the fast wetting process with low initial SWC, reduced soil infiltrability. As the initial SWC increased, the effect of soil aggregate breakdown on soil infiltrability weakened, thus, a positive influence of initial SWC on stable infiltration rate can be inferred. Therefore, water supply mode, as well as the soil texture and surface gradient, is confirmed to be an essential factor in water infiltration and soil loss.

These results demonstrated that higher initial SWC can cause a greater degree of aggregate slaking and lead to more severe aggregate breakdown, so soil loss was more evident under the action of rain splash. In this study, $16 \%$ initial SWC treatment had $315 \mathrm{~g}$ more soil loss than the $4 \%$ initial SWC treatment, which indicated that initial SWC not only affects the soil infiltration, but is also an important factor in soil loss. The analysis above provides a theoretical basis for the measurement of farmland water and soil conservation, particularly for the high SWC condition.

\subsection{Straw mulching affects soil infiltration and soil loss}

The results reported here also demonstrate that straw mulching treatment can delay runoff ${ }^{[4]}$ and enhance infiltration ${ }^{[48]}$. During rainfall events, the soil surface structure is damaged, and the pores in soil are filled and blocked by fine particles resulting from rain splash, thus infiltration is delayed ${ }^{[49]}$. Straw mulching treatment has a positive impact on soil infiltration by reducing the damage to soil aggregates by raindrops. In this study, with all the initial SWC, the 30\% SMR treatments significantly enhanced soil infiltration by $31.8 \%$ to $83.4 \%$. The 
sediment of sheet flow erosion is mainly caused by rain $\operatorname{splash}^{[50]}$, and therefore the positive influence of straw mulching treatment was also confirmed. Compared to the unmulched treatment, the $30 \%$ SMR significantly decreased soil erosion by $49.3 \%$ to $58.7 \%$, which was similar to the results of Pan et al. ${ }^{[51]}$. These results show that straw mulching decreases soil erosion by slowing the rapid increase in sediment in the early stage of runoff, and decreasing the average sediment yield rate during the steady infiltration stage. This can be explained by small dams formed by the straw on the soil surface resulting from the impact of runoff ${ }^{[52]}$, and the increased surface roughness caused by straw mulching, which can weaken runoff and reduce soil loss ${ }^{[53]}$.

With all initial SWC treatments, the $30 \%$ SMR treatment had a significant effect on water and soil retention. The results indicate that a straw mulching rate of over $30 \%$ can significantly reduce soil erosion and improve soil water retention, which is consistent with previous studies ${ }^{[54]}$. However, over mulching ( $>60 \%)$ may compromise the anti-blocking capacity of no-till planters, thus affecting seeding performance and grain production under conservation tillage in northern China ${ }^{[55]}$. In conclusion, for conservation tillage, 30\%-60\% maize straw mulching $\left(1400-3100 \mathrm{~kg} \cdot \mathrm{hm}^{-2}\right)$ is recommended to achieve high seeding performance and high efficient soil and water conservation, which is valuable information for conservation tillage of maize in northern China.

\section{Conclusions}

This study investigated the effects of straw mulching on water infiltration and soil loss under different initial SWC treatments, and showed the following.

(1) Increasing the initial SWC can decrease soil infiltration and increase soil loss. Under an $80 \mathrm{~mm}$ rainfall event, $8 \%, 12 \%$ and $16 \%$ initial SWC treatments decreased cumulative infiltrations by $8.7 \%, 42.5 \%$ and $58.1 \%$, and increased total sediment yields by 44,146 , and $315 \mathrm{~g}$, when compared to $4 \%$ initial SWC. However, in all the straw mulching treatments, there was no significant difference in stable infiltration rate for the different SWC treatments.

(2) With all initial SWC treatments, straw mulching of $30 \%$ or more significantly enhanced water infiltration by over $31 \%$ and reduced soil loss by more than $49 \%$, compared to the unmulched treatment. Taking into consideration the performance of no-till planters, $30 \%$ $60 \%$ maize straw mulching rate $\left(1400-3100 \mathrm{~kg} \cdot \mathrm{hm}^{-2}\right)$ is recommended for the conservation of water and soil in northern China.

Straw mulching significantly affects water infiltration and soil loss. The results from this study can provide a theoretical base for the management of maize straw under conservation tillage in northern China. The influence of the soil surface gradient should be investigated in future research on straw management in China.

Acknowledgements This work was supported by Changjiang Scholars and Innovative Research Team in University of China (IRT13039), and Special Fund for Agro-scientific Research in the Public Interest (201503136).

Compliance with ethics guidelines Yifu Zhang, Hongwen $\mathrm{Li}$, Jin $\mathrm{He}$, Qingjie Wang, Ying Chen, Wanzhi Chen, and Shaochun Ma declare that they have no conflict of interest or financial conflicts to disclose.

This article does not contain any studies with human or animal subjects performed by any of the authors.

\section{References}

1. Li H W, Gao H W, Wu H D, Li W Y, Wang X Y, He J. Effects of 15 years of conservation tillage on soil structure and productivity of wheat cultivation in northern China. Australian Journal of Soil Research, 2007, 45(5): 344-350

2. Li Z G, Gao W, Liu B Z, Luo Z D. Current status and developing trend of soil erosion in China. Science of Soil and Water Conservation, 2008, 6(1): 57-62 (in Chinese)

3. Iqbal M, Hassan A U, Ali A, Rizwanullah M. Residual effect of tillage and farm manure on some soil physical properties and growth of wheat (Triticum aestivum L.). International Journal of Agriculture and Biology, 2005, 7(1): 54-57

4. Ogban P I, Ekanem T P, Etim E A. Effect of mulching methods on soil properties and growth and yield of maize in south-eastern Nigeria. Tropical Agriculture, 2001, 78(2): 82-89

5. Gajri P R, Arora V K, Chaudhary M R. Maize growth responses to deep tillage, straw mulching and farmyard manure in coarse textured soils of N.W. India. Soil Use and Management, 1994, 10(1): 1519

6. Głąb T, Kulig B. Effect of mulch and tillage system on soil porosity under wheat (Triticum aestivum). Soil \& Tillage Research, 2008, 99 (2): 169-178

7. Adekalu K O, Olorunfemi I A, Osunbitan J A. Grass mulching effect on infiltration, surface runoff and soil loss of three agricultural soils in Nigeria. Bioresource Technology, 2007, 98(4): 912-917

8. Bhatt R, Khera K L. Effect of tillage and mode of straw mulch application on soil erosion in the submontaneous tract of Punjab, India. Soil \& Tillage Research, 2006, 88(1-2): 107-115

9. Nyssen J, Poesen J, Moeyersons J, Haile M, Deckers J. Dynamics of soil erosion rates and controlling factors in the Northern Ethiopian Highlands-towards a sediment budget. Earth Surface Processes and Landforms, 2008, 33(5): 695-711

10. Cameron M P, Liang X Q, Bruce A L, Kees J V G, Juhwan L, Mark E L, Natasja V G, Johan S, Rodney T V, Chris V K. Productivity limits and potentials of the principles of conservation agriculture. Nature, 2015, 517(7534): 365-368

11. He J, Wang Q J, Li H W, Liu L J, Gao H W. Effect of alternative tillage and residue cover on yield and water use efficiency in annual double cropping system in North China Plain. Soil \& Tillage Research, 2009, 104(1): 198-205

12. Wei W, Chen L D, Fu B J, Huang Z L, Wu D P, Gui L D. The effect of land uses and rainfall regimes on runoff and soil erosion in the 
semi-arid loess hilly area, China. Journal of Hydrology, 2007, 335 (3-4): 247-258

13. Shi Z H, Chen L D, Cai C F, Li Z X, Liu G H. Effects of long-term fertilization and mulch on soil fertility in contour hedgerow systems: a case study on steep lands from the Three Gorges Area, China. Nutrient Cycling in Agroecosystems, 2009, 84(1): 39-48

14. Erenstein O. Crop residue mulching in tropical and semi-tropical countries: an evaluation of residue availability and other technological implications. Soil \& Tillage Research, 2002, 67(2): 115-133

15. Shen Y H, Huang X G, Wang H Q. Field effects of straw mulching. Agricultural Research in the Arid Areas, 1998, 16(1): 45-50 (in Chinese)

16. Ghuman B S, Sur H S. Tillage and residue management effects on soil properties and yields of rainfed maize and wheat in a subhumid subtropical climate. Soil \& Tillage Research, 2001, 58(1-2): 1-10

17. Lu F, Wang X K, Han B, Ouyang Z Y, Duan X N, Zheng H, Miao H. Soil carbon sequestrations by nitrogen fertilizer application, straw return and no-tillage in China's cropland. Global Change Biology, 2009, 15(2): 281-305

18. Wang Z W, Hao W P, Gong D Z, Mei X R, Wang C T. Effect of straw mulch amount on dynamic changes of soil moisture and temperature in farm land. Chinese Journal of Agrometeorolog, 2010, 31(2): 244-250 (in Chinese)

19. Hawke R M, Price A G, Bryan R B. The effect of initial soil water content and rainfall intensity on near-surface soil hydrologic conductivity: a laboratory investigation. Catena, 2006, 65(3): 237-246

20. Bissonnais Y L, Singer M J. Crusting, runoff, and erosion response to soil water content and successive rainfalls. Soil Science Society of America Journal, 1992, 56(6): 1898-1903

21. Assouline S.Infiltration into soils: conceptual approaches and solutions. Water Resources Research, 2013, 49(4):1755-1772

22. Rudolph A, Helming K, Diestel H. Effect of antecedent soil water content and rainfall regime on microrelief changes. Soil Technology, 1997, 10(1): 69-81

23. Hino M, Odaka Y, Nadaoka K, Sato A. Effect of initial soil moisture content on the vertical infiltration process - a guide to the problem of runoff-ratio and loss. Journal of Hydrology, 1988, 102(1-4): 267-284

24. Tsuboyama Y, Sidle R C, Noguchi S, Hosoda I. Flow and solute transport through the soil matrix and macropores of a hillslope segment. Water Resources Research, 1994, 30(4): 879-890

25. Casenave A, Valentin C. A runoff capability classification system based on surface features criteria in semiarid areas of West Africa. Journal of Hydrology, 1992, 130(1-4): 231-249

26. Niu Q W, Fan X K, Zhou X B, Chen J Y. Effect of initial water content on soil infiltration characteristics during bubble irrigation. Journal of Drainage and Irrigation Machinery Engineering, 2012, 30(4): 491-496 (in Chinese)

27. Chen H S, Shao M A, Wang K L. Effects of initial water content on hillslope rainfall infiltration and soil water redistribution. Transactions of the Chinese Society of Agricultural Engineering, 2006, 22 (1): 44-47 (in Chinese)

28. Chen H X, Li F H, Hao S L, Fang X P. Effects of soil water content and soil sodicity on soil shearing strength. Transactions of the Chinese Society of Agricultural Engineering, 2007, 23(2): 21-25 (in
Chinese)

29. Fan Y W, Zhao W J, Wang Y. Influence of initial water content on parameters of Philip model of vertical one-dimensional infiltration. Journal of Lanzhou University of Technology, 2014, 40(5): 60-64 (in Chinese)

30. Liu H, Lei T W, Zhao J. Effects of initial soil water content and rainfall intensity on Loess infiltration capacity. Science of Soil \& Water Conservation, 2009, 7: 1-6 (in Chinese)

31. He Q J, Zhou G S. The climatic suitability for maize cultivation in China. Chinese Science Bulletin, 2012, 57(4): 395-403

32. Cai T Y, Jia Z K, Huang Y W, Huang H J, Yang B P, Zhang R, Hang Q F, Nie J F. Research progress of comprehensive effect under different rates straw mulch on the rainfed farming areas, China 1. Effect of different rates of straw mulch on farmland ecoenvironment. Agricultural Research in the Arid Areas, 2011, 29 (5): 63-68 (in Chinese)

33. Niu X S, Zhang H Y, Wang L G, Zhang F S, Li X L, Ma Y L. Effects of sowing winter wheat under no-till with maize straw mulching on soil microbial biomass carbon. Soil and Fertilizer Sciences in China, 2009, (1): 64-68,73 (in Chinese)

34. He J, McHugh A D, Li H E, Wang Q J, Li W Y, Rasaily R G, Li H. Permanent raised beds improved soil structure and yield of spring wheat in arid north-western China. Soil Use and Management, 2012, 28(4): 536-543

35. Wang H, Wang Q J, Shao M A. Simulation experiment of effect of antecedent soil moisture content on characteristics of runoff and sediment from two soil sloping lands. Transactions of the Chinese Society of Agricultural Engineering, 2008, 24(5): 65-68 (in Chinese)

36. Liu L S, Ren H Y, Shi X Z, Yu D S, Wang H J, Sun W X, Zhang L M. Effect of straw mulching on sediment yielding process of soil with different initial water contents. Transactions of the Chinese Society of Agricultural Engineering, 2010, 26(1): 108-112 (in Chinese)

37. Rooij G H D. Methods of soil analysis: part 4. physical methods. Vadose Zone Journal, 2004, 3(2): 722-723

38. Chowdary V M, Rao M D, Jaiswal C S. Study of infiltration process under different experimental conditions. Agricultural Water Management, 2006, 83(1-2): 69-78

39. Li Y, Shao M A. Experimental study on influence factors of rainfall and infiltration under artificial grassland coverage. Transactions of the Chinese Society of Agricultural Engineering, 2007, 23(3): 18-23 (in Chinese)

40. Hillel D. Crust Formation in Lassies soils. International Soil Science, 1960, 29(5): 330-337

41. Lado M, Ben-Hur M, Shainberg I. Soil wetting and texture effects on aggregate stability, seal formation, and erosion. Soil Science Society of America Journal, 2004, 68(6): 1992-1999

42. Levy G J, Mamedov A I. High-energy-moisture-characteristics aggregate stability as a predictor for seal formation. Soil Science Society of America Journal, 2002, 66(5): 1603-1609

43. Bodman G B, Colman E A. Moisture and energy condition during downward entry of water into soil. Soil Science Society of America Journal, 1994, 8(2): 166-182

44. Liu H, Lei T W, Zhao J, Yuan C P, Fan Y T, Qu L Q. Effects of rainfall intensity and antecedent soil water content on soil 
infiltrability under rainfall conditions using the run off-on-out method. Journal of Hydrology, 2011, 396(1-2): 24-32

45. Liu M X, Nie Y, Yu J. The infiltration process of clay soil under different initial soil water contents. Acta Ecologica Sinica, 2012, 32 (3): 871-878 (in Chinese)

46. Zhang J, Niu W Q, Zhang L L, Shi L Y, Wu Z G. Effects of soil initial water content on line-source infiltration characteristic in moistube irrigation. Journal of Drainage and Irrigation Machinery Engineering, 2014, 32(1): 72-79 (in Chinese)

47. Wang X Y, Gao H W, Li H W, Zhou X X. Experimental study on runoff and erosion under conservative tillage. Transactions of the Chinese Society of Agricultural Engineering, 2000, 16(3): 66-69 (in Chinese)

48. Zhang Y L, Zhang X C, Shao M A, Li S Q. Impact of straw cover on mineral nitrogen loss by runoff on loess slope. Journal of Soil and Water Conservation, 2004, 18(1): 85-88 (in Chinese)

49. Tang Z J, Lei T W, Zhang Q W, Zhao J. Quantitative determination of the impacts of raindrop splash and crust on soil erosion with ree experimental data. Acta Pedologica Sinica, 2004, 41(4): 632-635 (in Chinese)

50. Wu P T, Zhou P H. The effects of raindrop splash on the sheet flow hydraulic friction factor. Journal of Soil and Water Conservation, 1994, 8(2): 39-42

51. Pan C Z, Shangguan Z P. Hydraulic characteristics of silt-laden flow on different gradient grassplots and its mechanism of sediment retention. Advances in Water Science, 2007, 18(4): 490-495 (in Chinese)

52. Whelan M J, Anderson J M. Modeling spatial patterns of throughfall and interception loss in a Norway spruce (Picea abies) plantation at the plot scale. Journal of Hydrology, 1996, 186(1-4): 335-354

53. Zheng Z C, Wu F Q, He S Q, Wang J, She D. Effects of soil surface roughness on runoff and sediment discharges with laboratory experiments. Transactions of the Chinese Society of Agricultural Engineering, 2007, 23(10): 19-24 (in Chinese)

54. Zhang Y F, Li H W, He J, Wang Q J, Li W Y, Chen W Z, Zhang X $Y$. Effects of maize straw mulching on runoff and sediment process of slope. Transactions of the Chinese Society of Agricultural Engineering, 2015, 31(7): 118-124 (in Chinese)

55. Jia Y M, Shang Z Q, Zhang Z G. Adaptability test and key technology research on conservation Tillage. Transactions of the Chinese Society of Agricultural Engineering, 2002, 18(1): 78-81 (in Chinese) 